\title{
POTENSI "SANGGA BUWANA" DENGAN SUBSTITUSI TEPUNG SUKUN SEBAGAI MAKANAN SIAP SAJI YANG SEHAT
}

\author{
Marcellus Arnold - Rio Lawandra \\ Yolanda Victoria Rajagukguk - Tri Oktaviani - Emely \\ Program Studi Teknologi Pangan, Fakultas Ilmu Hayati, Universitas Surya, Tangerang \\ 15810 \\ marcellusarnold95@gmail.com
}

\begin{abstract}
During the reign of Sri Sultan Hamengkubuwono VII at Yogyakarta Palace, Sangga Buwana is a traditional food which arose up as a result of acculturation between local culture with European and Asian culture. The food symbolizes a confession of human towards the existence of God. When comparing to burger in terms of ingredients and the manner of serving, both of them are quite similar. The purpose of this research is to study the potency of Sangga Buwana as a bealthier fast food than burger. In addition, the investigation of the potency of local food utilization such as breadfruit (Artocorpus altilis) flour as wheat flour substitution in preparation of choux dough is also conducted. The study is conducted by literature research and interviews. The results showed that the substitution of wheat flour to breadfruit flour is potential to make Sangga Buwana as a healthier fast food because it has richer fiber, higher mineral, and lower fat content than wheat flour. Breadfruit flour can partially substitute the usage of wheat flour in the preparation of choux dough.
\end{abstract}

Keywords: Breadfruit Flour, Fast Food, Sangga Buwana, Yogyakarta Palace

\section{PENDAHULUAN}

Sangga Buwana merupakan salah satu makanan favorit Sri Sultan Hamengkubuwono VIII (HB VIII). Sangga Buwana mulai diperkenalkan di lingkungan keraton pada masa pemerintahan Sri Sultan HB VII, yang kemudian disempurnakan pada masa pemerintahan Sri Sultan HB VIII. Makanan Sangga Buwana sendiri diciptakan oleh R.W. Hendrobudjono yang memimpin Pawon Prabeyo di keraton pada masa pemerintahan HB VIII (19211939) (Gardjito et al. 2010; Wahyuni 2016). Makanan Sangga Buwana terdiri 
atas tiga bagian, yaitu kue sus isi rogut, telur ayam dipotong setengah parabola yang diletakkan di atas kue sus, serta bagian penyerta yang terdiri atas selada, acar timun, wortel, nanas, dan irisan bawang merah (Gardjito 2016).

Makanan ini biasanya disajikan ketika terdapat hajatan ataupun untuk penyambutan tamu dari luar negeri. Sangga Buwana adalah simbol pengakuan manusia atas kekuasaan Tuhan Yang Maha Esa (Gardjito 2016). "Sangga" memiliki arti menyangga dan "Buwana" yang berarti bumi/alam semesta. Masing-masing bahan makanan penyusun Sangga Buwana memiliki filosofi tersendiri, misalnya kue sus sebagai simbol bumi, selada sebagai simbol tanaman yang menyangga bumi, dan rogut daging melambangkan rakyat serta keanekaragaman di dalam bumi. Kemudian ada telur ayam rebus sebagai gunung, mayones sebagai langit, dan acar sebagai bintang (Sunjata 2016). Harapannya ketika Sangga Buwana disantap, manusia dapat selalu ingat akan lingkungan sebagai anugerah dari Sang Pencipta (Gardjito 2016).

Secara umum, komposisi bahan dasar Sangga Buwana dengan burger tidak jauh berbeda, yaitu bahan tinggi karbohidrat yaitu kue sus, bahan tinggi protein seperti telur rebus dan rogut ayam, serta bahan-bahan tambahan lainnya seperti selada, timun (acar), dan mayones. Selain itu, dari cara penyajian dan lama penyajiannya juga tidak jauh berbeda dengan burger. Bahan-bahan dasar Sangga Buwana ditumpuk jadi satu berdasarkan filosofi penyusunannya. Oleh karena itu, Sangga Buwana memiliki potensi untuk dikomersialisasikan sebagai makanan cepat saji khas Indonesia karena cara penyajiannya yang tidak jauh berbeda dengan burger.

Pada umumnya, makanan cepat saji seperti burger memiliki kandungan serat yang rendah dan lemak trans yang tinggi yang dapat meningkatkan risiko terserang penyakit obesitas, diabetes tipe 2, dan penyakit jantung (Elhak et al 2014). Hal ini menjadi tantangan bagi pelaku industri fast food dalam memberikan makanan yang praktis dan juga sehat bagi konsumen. Tingginya kadar gula dan lemak dapat menjadi faktor utama penyebab penyakit obesitas, diabetes, dan penyakit jantung pada konsumsi fast food yang berlebihan (Hutapea 2016). Pemanfaatan pangan lokal pada Sangga Buwana cukup berpotensi menurunkan risiko penyakit tersebut. Oleh karena itu, penelitian ini bertujuan mengkaji pemanfaatan bahan baku lokal khas Yogyakarta untuk 
memperkaya kandungan gizi Sangga Buwana serta mengetahui potensi Sangga Buwana sebagai fast food khas Indonesia.

Salah satu bahan baku lokal yang dapat dimanfaatkan di Yogyakarta adalah sukun (Articorpus altilis). Sukun mengalami kenaikan produksi di Yogyakarta pada tahun 2012 hingga 2013 sebanyak 8,36\% (BPS DIY 2014). Salah satu produk lanjutan dari sukun adalah tepung sukun. Tepung sukun memiliki beberapa khasiat dan juga kandungan nutrisi yang lebih baik dibandingkan tepung terigu, khususnya serat dan juga abu (Bakare et al. 2016). Tepung sukun dapat dimanfaatkan untuk membuat adonan (dough) atau bahan baku pangan lainnya (Adepeju et al. 2011). Beberapa produk olahan seperti kue (cake), mi, cookies, dan juga kue tradisional yang kebanyakan menggunakan tepung terigu, saat ini sudah banyak yang disubstitusi dengan menggunakan tepung sukun (Waryat et al. 2014).

\section{METODE}

\section{Desain}

Penelitian mengenai sejarah dan filosofi Sangga Buwana bersifat kualitatif dengan wawancara bersama narasumber di bidangnya. Narasumber tersebut antara lain Prof Dr Ir Murdijati Gardjito (Peneliti Ilmu dan Teknologi Pascapanen Universitas Gadjah Mada), Wahjudi Pantja Sunjata, S S (Peneliti madya bidang Tradisi dan Mitologi dari Instansi Balai Pelestarian Nilai Budaya Daerah Istimewa Yogyakarta), Nur Wahyuni, M Pd (Peneliti Kebudayaan AKS AKK Yogyakarta), dan Prapto Yuwono, S S, M Hum (Peneliti Kebudaayaan Jawa di Fakultas Ilmu dan Budaya Universitas Indonesia). Adapun potensi sukun sebagai bahan substitusi tepung terigu dianalisis secara komparatif.

\section{Tempat dan Waktu}

Penggalian data penelitian dilakukan di Tempat Narasumber (tatap muka) dan di Kampus Universitas Surya yang beralamat di Jalan Boulevard Gading Serpong kav M5 no. 21 Summarecon Serpong, Tangerang, Banten 15810. Penelitian, pengolahan, analisis, dan penyusunan artikel dilakukan dalam kurun waktu Oktober - Desember 2016. 
Potensi Sangga Buwana dengan......

\section{Jenis dan Cara Pengumpulan Data}

Cara pengumpulan data mengenai sejarah dan filosofi Sangga Buwana dilakukan dengan wawancara langsung keempat narasumber melalui tatap muka, telepon, skype, dan surat elektronik (emai). Jenis data yang diambil selama wawancara adalah data primer. Data mengenai potensi pangan lokal dikumpulkan melalui studi literatur yang bersumber dari buku, artikel jurnal ilmiah, serta sumber pustaka lainnya. Jenis data yang diambil dari studi literatur ini adalah data sekunder.

\section{HASIL DAN PEMBAHASAN}

\section{Potensi Sangga Buwana sebagai Makanan Cepat Saji Khas Yogyakarta}

Makanan cepat saji atau seringkali disebut sebagai fast food merupakan makanan yang disajikan secara cepat, praktis, dan waktu persiapannya membutuhkan waktu yang singkat, sehingga dapat dihidangkan kapan dan di mana saja dengan menghemat waktu serta penyajian yang higienis (Juwaedah 2011). Menurut Nilsen (2008), sebanyak 69\% masyarakat kota di Indonesia mengonsumsi fast food. Perubahan gaya hidup masyarakat Indonesia terutama di kota-kota besar menjurus ke westernisasi dan sedentari (gaya hidup malas) menyebabkan adanya perubahan pola konsumsi masyarakat menuju makanan yang praktis dan dapat disantap kapanpun dan dimanapun (Boenga 2011 dalam Wulandary 2016).

Perkembangan makanan cepat saji cukup signifikan berdasarkan data ukuran pasar beberapa sektor industri di Indonesia, yakni 18,1\% pada tahun 2006, kemudian 22,1\% pada tahun 2007 (Marellin 2010). Pada tahun 2011, Gabungan Pengusaha Makanan dan Minuman Indonesia (GAPMMI) mencatat bahwa nilai penjualan makanan cepat saji menduduki peringkat teratas, disusul oleh padi-padian (cereals), sayur-sayuran (vegetables), ikan (fish), dan daging (meat). Hal ini menunjukkan bahwa industri makanan cepat saji di Indonesia berpotensi dan terus bertumbuh dari tahun ke tahun.

Kebanyakan makanan fast food saat ini merupakan makanan yang rendah serat dan tinggi lemak seperti burger yang mengandung lemak trans yang tinggi yang dapat meningkatkan risiko terserang penyakit obesitas, diabetes tipe 2, dan penyakit jantung (Elhak et al. 2014). Hal ini dikarenakan komposisi bahan burger yang tinggi karbohidrat dan lemak seperti roti, patty 
(daging giling), mayones, dan keju serta mengesampingkan komposisi bahan yang tinggi serat seperti selada, timun, dan acar. Hal ini menjadi tantangan bagi industri fast food dalam memberikan makanan yang praktis dan juga sehat bagi konsumen.

Sangga Buwana merupakan salah satu makanan favorit Sri Sultan HB VIII yang biasanya disantap sebagai makanan pembuka (Sunjata 2016). Makanan ini muncul di zaman Sultan HB VIII di Keraton Yogyakarta pada masa pengaruh bangsa Belanda (Yuwono 2016). Makanan kurang bergizi yang dikonsumsi rakyatnya merupakan alasan untuk memberikan ajaran bahwa Sangga Buwana merupakan salah satu contoh makanan bergizi kekeratonan di masa tersebut (Wahyuni, 2016).

Sangga Buwana merupakan makanan hasil akulturasi budaya lokal dengan budaya Eropa dan Asia. Sangga Buwana ini terdiri atas bahan-bahan yang kurang lebih mirip dengan burger dari segi jenis bahan yaitu ada bahan tinggi karbohidrat, bahan tinggi protein, dan bahan tinggi serat. Berbeda dengan burger yang menggunakan roti, patty, dan selada serta acar, bahanbahan yang digunakan pada Sangga Buwana adalah kue sus, rogut daging, telur ayam rebus, selada, mayones, dan acar. Penyajiannya tidak jauh berbeda dengan burger yaitu bahan-bahan tersebut cukup ditumpuk dan disusun menjadi satu dalam waktu yang singkat.

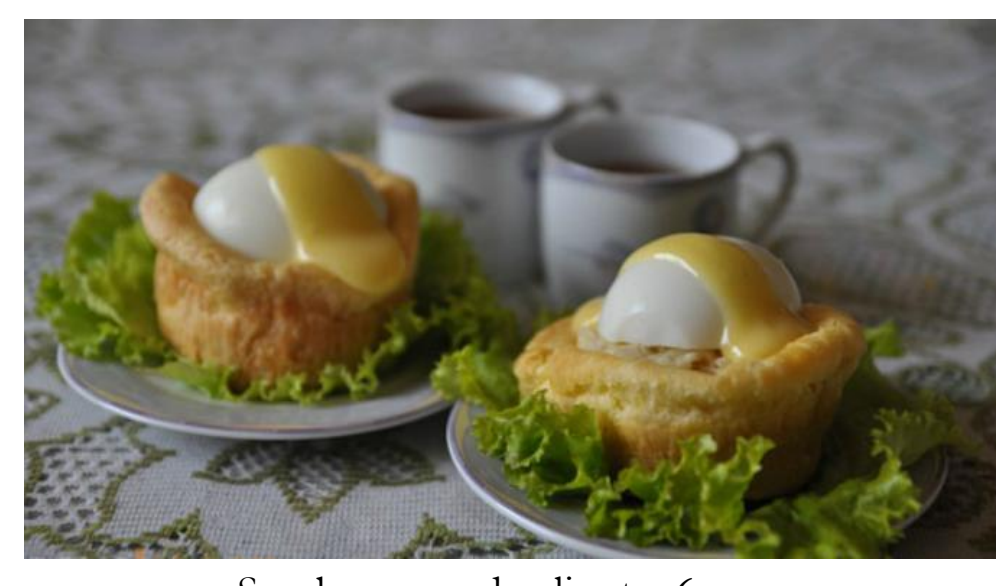

Sumber: ramadan.liputan6.com

Gambar 1. Sangga Buwana 
Pembuatan rogut pada Sangga Buwana berbahan dasar dada ayam cenderung memiliki kandungan lemak trans lebih rendah dibandingkan dengan patty yang digunakan pada burger. Bahan pelengkap seperti mayones yang digunakan pada Sangga Buwana juga bisa dibuat dari buah sukun yang lebih rendah lemak dibandingkan mayones dari kuning telur yang memiliki kandungan lemak yang tinggi (Hutapea 2006). Kue sus yang terbuat dari tepung sukun juga berpotensi memiliki kandungan serat yang lebih tinggi dibandingkan dengan tepung terigu. Kandungan serat pada biskuit meningkat seiring dengan meningkatnya komposisi tepung sukun sebagai pengganti tepung terigu (Olaoye et al. 2007). Meskipun Sangga Buwana berpotensi dijadikan sebagai makanan cepat saji lokal yang sehat, perlu studi analisis lebih lanjut untuk membuktikan bahwa kandungan gizi dari Sangga Buwana lebih baik dibandingkan burger.

\section{Potensi Tepung Sukun sebagai Substitusi Tepung Terigu dalam Membuat Kue Sus Sangga Buwana}

Salah satu bahan utama dalam membuat Sangga Buwana adalah tepung terigu yang masih diimpor dari negara lain. Menurut Kementerian Pertanian Republik Indonesia (2012), terjadi rata-rata pertumbuhan impor tepung terigu sebanyak 5,12\% dari tahun 2007 hingga 2011 di Indonesia. Oleh karena itu, perlu dilakukan diversifikasi pangan untuk mengatasi tingginya impor tepung terigu. Salah satu contoh upaya diversifikasi pangan adalah dengan memanfaatkan tepung sukun sebagai bahan substitusi tepung terigu dalam pembuatan kue sus Sangga Buwana. Menurut Elizabeth (2011), alasan diperlukannya diversifikasi pangan antara lain: (i) mengonsumsi pangan beragam sebagai alternatif terbaik untuk pengembangan sumber daya manusia yang berkualitas, (ii) mampu mengoptimalkan pemanfaatan sumber daya pertanian dan kehutanan, (iii) mengurangi ketergantungan kepada pangan impor dengan mempduksi pangan yang beragam, (iv) mewujudkan ketahanan pangan yang merupakan tanggung jawab pemerintah dan masyarakat.

Buah sukun merupakan salah satu pangan lokal yang diproduksi di Yogyakarta yang berpotensi untuk dimanfaatkan sebagai pangan lokal. Balai Besar Penelitian Bioteknologi dan Pemuliaan Tanaman Hutan Yogyakarta sudah melakukan penanaman sukun di Gunung Kidul, Daerah Istimewa 
Yogyakarta untuk mengetahui variasi kemampuan tumbuh dan kemampuan menghasilkan buah dari beberapa bibit seperti dari Lampung, Jawa, dan Papua (Adinugraha et al. 2014). Adinugraha dan Kartikawati (2012) melaporkan bahwa buah sukun Yogyakarta rata-rata memiliki berat buah 1,38 $\mathrm{kg}$, panjang buah 13,36 cm, berbentuk bulat-lonjong, berwarna hijau muda, dan tidak berduri. Buah sukun juga menjadi salah satu dari delapan komoditas yang mengalami kenaikan produksi di Yogyakarta, yaitu sebanyak 8,36\% (BPS DIY 2014).

Buah sukun dapat menjadi sumber energi karena memiliki kandungan karbohidrat yang tinggi. Total karbohidrat dari buah sukun mencapai 84\%, dengan kandungan pati sebanyak 68,38-69,20\%. Karbohidrat dari tepung sukun adalah karbohidrat yang kompleks (Putri \& Zubaidah 2015). Selain itu, buah sukun juga mengandung 4,31-4,85\% protein kasar, 5,00-5,38\% serat kasar, 2,11\%-2,90\% lemak, 2,56-2,90\% abu (Oladunjoye et al. 2010). Adinugraha dan Kartikawati (2012) melaporkan bahwa jumlah energi (79,49$136,40 \mathrm{kal} / 100 \mathrm{~g})$ yang dihasilkan dari buah sukun di Pulau Jawa, termasuk Yogyakarta, relatif lebih besar dibandingkan energi dari buah sukun di luar Pulau Jawa (41,19-106,13 kal/100 g).

Untuk meningkatkan masa simpannya, buah sukun yang kaya akan karbohidrat dapat diolah menjadi tepung sukun (Fatmawati 2012). Bakare et al. (2016) melaporkan komposisi dari tepung terigu, tepung sukun, dan campuran dari keduanya. Hasil yang didapatkan yaitu semakin tinggi persentase dari tepung sukun (TS) atau semakin rendah persentase dari tepung terigu (T'T), maka kandungan gluten dari produk menjadi semakin rendah secara signifikan $(\mathrm{P}<0,05)$. Gisslen (2009) menyebutkan bahwa untuk produk pastry (termasuk kue sus), dibutuhkan tepung dengan kadar gluten yang rendah dan kadar proteinnya sekitar 9\%. Dalam penelitian Bakare et al. (2016), kandungan protein dari TS:TT sebesar 10:90; 20:80; 30:60; dan 60:40 secara berturut-turut adalah $11,1 \pm 0,3 \% ; 10,3 \pm 0,3 \% ; 8,59 \pm 0,3 \% ; 6,71 \pm 0,1 \%$. Persentase protein ini berada di sekitar 9\% (Tabel 1). Oleh sebab itu, tepung sukun berpotensi menjadi substitusi parsial dari tepung terigu dalam membuat kue sus dari Sangga Buwana. 
Tabel 1. Kandungan gizi tepung sukun, tepung terigu, dan campurannya

\begin{tabular}{|c|c|c|c|c|c|}
\hline $\begin{array}{l}\text { Tepung } \\
\text { (TS:TT) }\end{array}$ & $\begin{array}{c}\text { Kadar Air } \\
(\%)\end{array}$ & $\begin{array}{c}\text { Protein } \\
(\%)\end{array}$ & Abu $(\%)$ & $\begin{array}{c}\text { Gluten } \\
(\%)\end{array}$ & Serat $(\%)$ \\
\hline 00:100 & $12,5 \pm 0,3^{a}$ & $10,9 \pm 0,1^{\mathrm{de}}$ & $0,65 \pm 0,01^{a}$ & $12,8 \pm 0,1^{\mathrm{e}}$ & $2,81 \pm 0,7$ \\
\hline 100:00\# & $13,7 \pm 0,2^{\mathrm{b}}$ & $2,6 \pm 0,1^{a}$ & $1,72 \pm 0,01^{\mathrm{f}}$ & N.A. & $7,79 \pm 0,6$ \\
\hline 10:90 & $13,7 \pm 0,2^{b}$ & $11,1 \pm 0,3^{\mathrm{e}}$ & $0,83 \pm 0,0^{\mathrm{b}}$ & $11,6 \pm 0,1^{\mathrm{d}}$ & \\
\hline $20: 80$ & $12,8 \pm 0,1^{\mathrm{ba}}$ & $10,3 \pm 0,3^{d}$ & $0,98 \pm 0,0 c$ & $9,8 \pm 0,1^{c}$ & \\
\hline $30: 60$ & $12,5 \pm 0,2^{a}$ & $8,59 \pm 0,3^{c}$ & $1,31 \pm 0,01^{\mathrm{d}}$ & $7,6 \pm 0,2^{\mathrm{b}}$ & \\
\hline $60: 40$ & $12,5 \pm 0,1^{a}$ & $6,71 \pm 0,1^{b}$ & $1,41 \pm 0,01^{\mathrm{e}}$ & $5,8 \pm 0,1^{a}$ & \\
\hline
\end{tabular}

a-f, rata-rata pada kolom yang sama tidak memberikan beda yang signifikan $(\mathrm{P}<0,05)$; TS, Tepung Sukun; TT, Tepung Terigu; N.D., Tidak Ditentukan; N.A., Tidak Tersedia; \# = level substitusi.

Sumber: Bakare et al. (2016)

Olaoye et al. (2007) mengaplikasikan tepung sukun dalam membuat produk biskuit dengan mencampurkannya dengan tepung terigu. Hasil menunjukkan bahwa seiring meningkatnya proporsi tepung sukun (dari $0 \%$ sampai 25\% tepung sukun), maka kandungan serat kasarnya juga meningkat dari 1,03\% sampai 4,98\%. Tepung sukun ini memiliki manfaat dalam sistem pencernaan manusia. Selain itu, kandungan lemak dari biskuit juga menurun sedikit seiring dengan meningkatnya proporsi dari tepung sukun. Lemak dapat berpengaruh terhadap umur simpan dari produk pangan dan kandungan lemak yang tinggi tidak diharapkan dari baked products. Kandungan lemak yang tinggi dapat menyebabkan ketengikan dan menghasilkan aroma yang tidak menyenangkan.

Kandungan abu juga meningkat seiring dengan meningkatnya proporsi tepung sukun. Meningkatnya kadar abu dapat berarti semakin banyak asupan mineral apabila dikonsumsi, sebab jumlah abu mengindikasikan jumlah dari 
mineral yang terkandung dalam produk pangan (Olaoye et al. 2007). Fosfor dan kalsium merupakan kandungan mineral yang banyak ditemukan pada sukun (Adinugraha \& Kartikawati, 2014). Apabila tepung sukun diaplikasikan pada kue sus, maka dapat berpotensi untuk memperbaiki nilai gizi dari Sangga Buwana, khususnya peningkatan kandungan serat, abu, dan penurunan kadar lemaknya.

\section{KESIMPULAN}

Secara umum, komposisi bahan dasar, cara penyajian, dan lama penyajian Sangga Buwana dengan burger tidak jauh berbeda, sehingga sangga buwana dapat jg dimanfaatkan sbg mknn cepat saji. Bahkan, lebih sehat dibanding burger apabila memanfaatkan tepung sukun sebagai substitusi parsial tepung terigu dalam pembuatan kue sus yang merupakan salah satu komposisi Sangga Buwana. Hal ini dikarenakan tepung sukun kaya serat, tinggi mineral, dan lemaknya jauh lebih rendah dibanding tepung terigu. Penelitian selanjutnya perlu dilakukan dengan melakukan analisis kandungan zat gizi pada sampel Sangga Buwana tanpa substitusi tepung sukun dan sampel yang telah disubstitusi dengan tepung sukun secara parsial maupun penuh. Hasil analisis dari sampel tersebut kemudian dapat dibandingkan satu sama lain untuk mengetahui pengaruh dari pemanfaatan tepung sukun.

\section{PUSTAKA}

Adepeju AB, Gbadamosi SO, Adeniran AH, Omobuwajo TO. 2011. Functional and Pasting Characteristics of Breadfruit (Artocarpus altilis) Flours. Afr J Food Sci 5(9): 529-535.

Adinugraha HA, Kartikawati NK, Setiadi D, Prastyono. 2014. Pengembahan Teknik Budidaya Sukun (Artocarpus altilis) untuk Ketahanan Pangan. Jakarta: IPB Press.

Adinugraha HA, Kartikawati NK. 2012. Variasi Morfologi dan Kandungan Gizi Buah Sukun. Wana Benih 13(2): 99-106. 
Potensi Sangga Buwana dengan......

Badan Pusat Statistik Provinsi Daerah Istimewa Yogyakarta. 2014. Statistik Hortikultura Daerah Istimewa Yogyakarta 2013. Yogyakarta: Badan Pusat Statistik Provinsi Daerah Istimewa Yogyakarta.

Bakare AH, Osundahunsi OF, Olusanya JO. 2016. Rheological, Baking, and Sensory Properties of Composite Bread Dough with Breadfruit (Artocarpus communis Forst) and Wheat Flours. Food Science \& Nutrition 4(4): 573-587. DOI: 10.1002/fsn3.321.

Elhak ABD, Nasra A, Ali SE, Zaki NL. 2014. Innovative Modification of Traditional Burger. Egypt J Agric Res, 92(3): 995-1008.

Elizabeth R. 2011. Strategi Pencapaian Diversifikasi dan Kemandirian Pangan: Antara Harapan dan Kenyataan. Iptek Tanaman Pangan 6(2): 230-242.

Fatmawati WT. 2012. Pemanfaatan Tepung Sukun dalam Pembuatan Produk Cookies [Proyek Akhir]. Yogyakarta: Program Studi Teknik Boga, Fakultas Teknik, Universitas Negeri Yogyakarta.

Gardjito M, Indrati R, Amaliah. 2010. Menu Favorit Para Raja: Potret Kekayaan Kuliner Yogyakarta "Kersanan Ndalem". Yogyakarta: Kanisius.

Gardjito M. 2016. Sangga Buwana. [murgardjito@yahoo.com] Email tanggal 1 Desember 2016.

Gisslen W. 2009. Professional Baking $5^{\text {th }}$ Edition. New Jersey: John Wiley \& Sons, Inc.

Hutapea CA. 2016. Pengaruh Perbandingan Zat Penstabil dan Konsentrasi Kuning Telur Terhadap Mutu Reduced Fat Mayonnaise [Skripsi]. Medan: Program Studi Ilmu dan Teknologi Pangan, Fakultas Pertanian, Universitas Sumatera Utara.

Juwaedah A. 2011. Makanan Siap Hidang, Fast Food. Bandung: PKK FPTK Universitas Pendidikan Indonesia.

Kementerian Pertanian Republik Indonesia. 2012. Statistik Konsumsi Pangan Tahun 2012. Jakarta: Pusat Data dan Sistem Informasi Pertanian, Kementerian Pertanian Republik Indonesia.

Marellin AK. 2010. Analisis Dampak Inovasi Produk Pizza Hut dalam Meningkatkan Keputusan Pembelian di Pizza Hut King’s Plaza: Survei pada Pengunjung Restoran Pizza Hut King’s Plaza Bandung [Skripsi]. 
Bandung: Manajemen Pemasaran Pariwisata, Universitas Pendidikan Indonesia.

Nilsen AC. 2008. Majalah Appetite Journey, 1/V/Okt 2008: 22.

Oladunjoye IO, Ologhobo AD, Olaniyi CO. 2010. Nutrient Composition,

Energy Value and Residual Anti-Nutritional Factors in Differently Processed Breadfruit (Artocarpus altilis) Meal. Afr J Biotechnol 9(27): 4259-4263. DOI: 10.5897/AJB09.1665.

Olaoye OA, Onilude AA, Oladoye CO. 2007. Breadfruit Flour in Biscuit Making: Effects on Product Quality. Afr J Food Sci: 20-23.

Putri WDR, Zubaidah E. 2015. Karakteristik Fungsional Tepung Sukun Hasil

Modifikasi Annealing. Prosiding Seminar Agroindustri dan Lokakarya Nasional FKPT-TPI, 2-3 September 2015 (hlm. 178-184). Madura:

Program Studi Teknologi Industri Pertanian, Universitas Trunojoyo Madura.

Sunjata WP. 2016. Makanan Keraton Sangga Buwana. Wawancara dilakukan oleh Arnold M, Lawandra R, Rajagukguk YV, Emely, dan Oktaviani T pada tanggal 21 Oktober 2016, pukul 08.30 WIB.

Wahyuni N. 2016. Makanan Keraton Sangga Buwana. Wawancara dilakukan oleh Arnold M, Lawandra R, Rajagukguk YV, Emely, dan Oktaviani T pada tanggal 1 November 2016 pukul 14.05 WIB.

Waryat, Yanis M, Handayani Y. 2014. Diversifikasi Pangan dari Tepung Sukun untuk Mengurangi Konsumsi Tepung Terigu di Kepulauan Seribu, Provinsi DKI Jakarta. Buletin Pertanian Perkotaan 4(1): 13-19.

Wulandary IS. 2016. Hubungan Antara Status Gizi, Persentase Lemak Tubuh, Asupan Zat Gizi (Protein, Lemak Dan Kalsium) dan Keterpaparan Media Informasi Dengan Usia Menarche dan Semenarche Pada Remaja di SMP Negeri 191 Jakarta Tahun 2016 [Skripsi]. Jakarta: Fakultas Ilmu Kesehatan, Universitas Esa Unggul.

Yuwono P. 2016. Kuliner Keraton Masa Pemerintahan Sultan Hamengkubuwono VII, VIII, dan IX. Wawancara dilakukan oleh Arnold M, Lawandra R, Rajagukguk YV, Emely, dan Oktaviani T pada tanggal 25 Oktober 2016, pukul 13.30 WIB. 